given as a routine to patients who respond, have not been shown to outweigh the long term disadvantages.

Thus the treatment of patients with small cell lung cancer remains difficult, and in dealing with an aging population (the mean age in most studies has been between 55 and 65) the potential toxicity of treatment must be weighed against the potential for improved survival rates and possible long term survival. There have been few studies assessing quality of life, but in patients who presented with symptoms (as most do) such as anorexia, loss of weight, malaise, haemoptysis, bone pain, or obstruction of the superior vena cava, nearly three quarters had their symptoms relieved by three months, or four courses, of chemotherapy. ${ }^{18}$ The optimal duration of chemotherapy is being investigated. The benefits from treatment seem to occur early and side effects tend to occur later, becoming more noticeable as treatment is prolonged. Data on long term survival suggest that 12 to 18 months' treatment is necessary, but whether this is the optimum duration of treatment is not known, and recent studies of shorter treatment regimens with three and six courses of chemotherapy followed by chest irradiation have shown no difference in median survival. ${ }^{19}$

Current studies should show whether all patients with small cell lung cancer should be treated similarly or whether shorter courses of chemotherapy are more appropriate for giving symptomatic relief in patients with extensive and usually incurable disease. Long term survival occurs in 10$15 \%$ of patients with limited disease, minimal symptoms, small tumour volume, and other favourable prognostic factors. Nevertheless, the optimal duration of chemotherapy, the place of additional radiotherapy, the cause of late neurological sequelae, and the value of further chemotherapy to treat long term survivors who relapse have yet to be defined. Thus further work is needed if we are to improve our management of this aggressive disease.

STEPHEN G SPIRO

Consultant Physician,

Brompton Hospital,

London SW3 6HP

1 Zelen M. Keynote address on biostatistics and data retrieval. Cancer Chemotherapy Reports 1973;4(suppl):31-42.

2 Hande KR, Des Prez RM. Current perspectives in small cell lung cancer. Chest 1984;85:669-77. 3 Greco FA, Einhorn LH, Richardson RL, Oldham RK. Small cell lung cancer: progress and perspectives. Semin Oncol 1978;5:323-35.

4 Morstyn G, Ihde DC, Lichter AS, et al. Small cell lung cancer 1973-1983: early progress and recent obstacles. Int f Radiat Oncol Biol Phys 1984;10:515-39.

5 Oldham RK, Greco FA. Small-cell lung cancer: a curable disease. Cancer Chemother Pharmacol 1980;4:173-7.

6 Hansen HH, Dombernowsky P, Hansen HS, Rorth M. Chemotherapy versus chemotherapy plus radiotherapy in regional small cell carcinoma of the lung-a randomised trial. Proceedings of the American Association for Cancer Research 1979;20:277.

7 Fox RN, Woods RL, Brodie GN, Tattersall MH. A randomised study: small cell anaplastic lung cancer treated by combination chemotherapy and adjuvant radiotherapy. Int $\mathcal{F}$ Radiat Oncol Biol Phys 1980;6:1083-5.

8 Souhami RL, Geddes DM, Spiro SG, et al. Radiotherapy in small cell cancer of the lung treated with combination chemotherapy: a controlled trial. Br Med J 1984;288:1643-6.

9 Stevens E, Einhorn L, Rohn R. Treatment of limited small cell lung cancer. Proceedings of the American Association for Cancer Research 1979;20:435.

10 Bunn PA, Ihde DC. Small cell bronchogenic carcinoma: a review of therapeutic results. In: Livingstone RB, ed. Lung cancer 1. London: Martinus Niihoff, 1981:169-208.

11 Harper PG, Souhami RL, Spiro SG, et al. Tumor size, response rate, and prognosis in small cell carcinoma of the bronchus treated by combination chemotherapy. Cancer Treat Rep 1982;66:463-70.

12 Ihde DC, Makuch RW, Carney DN, et al. Prognostic implications of stage of disease and sites of metastases in patients with small cell carcinoma of the lung treated with intensive combination chemotherapy. Am Rev Respir Dis 1981;123:500-7.

13 Cohen MH, Makuch RW, Johnston-Early A, et al. Laboratory parameters as an alternative to performance status in prognostic stratification of patients with small cell lung cancer. Cancer Treat Rep 1981;65:187-95.

14 Johnson BE, Ihde DC, Lichter AS, et al. Five to 10 year follow up of small cell lung cancer (SCLC) patients disease free at 30 months: chronic toxicities and late relapses. Proceedings of the American Society for Clinical Oncology 1984;25:218.

15 Kalter S, Farha P, Carr DT, Jefrries D, Lee JS, Valdivieso M. Long term survivors with small cell lung cancer (SCLC): the MD Anderson (MDA) experience from 1972-1980. Proceedings of the American Society for Clinical Oncology 1984;25:229.

16 Catane R, Schwade JG, Yarr I, et al. Follow-up neurological evaluation in patients with small cell lung cancer treated with prophylactic cranial irradiation and chemotherapy. Int $\mathcal{Y}$ Radiat Oncol Biol Phys 1981;7:105-9.
17 Livingston RB. Long-term survivors with small-cell lung cancer (SCLC): a South West Oncology Group (SWOG) study. Proceedings of the American Society for Clinical Oncology $\longrightarrow$ 1983;2:187.

18 Geddes DM, Spiro SG, Souhami RL, Harper PG, Tobias JS, Shah S. Symptom response to chemotherapy in small cell lung cancer. Eur $\mathcal{F}$ Respir Dis 1982;63(suppl 125):36.

19 Feld R, Evans WK, DeBoer G, et al. Combined modality induction therapy withour maintenance chemotherapy for small cell carcinoma of the lung. Fournal of Clinical Oncology $1984 ; 2: 294-304$

\section{Platelets and coronary disease, round three}

A fresh thrombus consists of masses of platelets stuck to each ${ }^{\infty}$ other, supported by a mesh of fibrin strands. Arterial $\overrightarrow{0}$ thrombosis usually occurs in association with an atheroma- $\overrightarrow{\vec{\omega}}$ tous plaque, and it seems likely that the development of plaque is the result of repeated thrombotic episodes. ${ }^{1}$ Thus $\frac{0}{3}$ platelets may have an important role in arterial disease and in the sudden clinical events, such as myocardial infarction, $\mathscr{Ð}$ that accompany it. Furthermore, it seems reasonable to expect that patients with arterial disease or thrombosis would have stickier platelets than healthy subjects, and many tests of platelet function have been devised to test this hypothesis. $\overrightarrow{+}$

On page $428 \mathrm{Dr} \mathrm{T} W$ Meade and his colleagues describe $\mathrm{O}$ an epidemiological study of what they call platelet aggreg- 0 ability. The technique they used is a modification of Born's $\frac{\Phi}{O}$ optical density method, ${ }^{2}$ which measures changes in the transmission of light through platelet rich plasma as platelets form clumps in response to the addition of aggregating agents $\vec{\oplus}$ such as adenosine diphosphate. In this modified method $10^{\circ}$ concentrations of adenosine diphosphate are tested to estimate the maximum velocity of the change in the transmission? of light (which corresponds to the maximum rate of clump formation) and from this the $\mathrm{ED}_{50}$, or estimated dose of adenosine diphosphate that causes half the maximum $\frac{\AA}{\varnothing}$ response, is calculated.

The platelet aggregability of 958 subjects was studied, of 3 whom 24 had a history of ischaemic heart disease and $54 ?$ evidence of ischaemia in the electrocardiogram. In some? respects aggregability followed the same trends as the risk factors for coronary disease-for example, it increased with age-but in others it did not, being less marked in men; than women and not increased by smoking or by oral contraceptives. The range of $\mathrm{ED}_{50}$ was wide, and, althougho patients with coronary disease had more aggregable platelets than healthy controls, the difference was not significant. This may have been because there were few subjects with coronary $N$ disease, and it would be helpful to know what would be $\frac{}{2}$ found if the study was repeated on a larger group of patients with age and sex matched control subjects. The observations 0 are, however, consistent with the prevalent view that, thoughw there is a difference in platelet behaviour between groups of healthy subjects and groups of patients with coronary을 disease, it is not possible to show specific platelet abnormalities in individual patients. ${ }^{3}$ This concept represents round three of the platelet and thrombosis story.

Born's original aggregation method was designed to study the formation of clumps of platelets in a test tube. Differences $\frac{\mathbb{Q}}{\mathbb{Q}}$ between groups of patients and healthy subjects were shown, ${ }^{4}{ }^{4}$ but the technique was never found to be useful for identify-o ing individual subjects with vascular disease. In round one of the platelet and vascular disease story, which took place in the early 1960s, many other tests of platelet function were? used and measurements of platelets in whole blood sticking 
to glass emerged as a good way to identify "hypersensitive" people. ${ }^{56}$ These glass adhesive tests were difficult to perform, but the best test to separate patients with vascular disease from healthy subjects - the platelet electrophoretic response to low doses of adenosine diphosphate $\mathrm{e}^{7.9}$ - was even more tedious and, worse, was only semiquantitative. Experiments with this technique suggested that the platelets responded abnormally to adenosine diphosphate because of a factor present in the plasma, but the nature of this component was never elucidated fully. The technique that survived was measurement of platelet aggregation, which is relatively quick and easy to perform. Nevertheless, in clinical studies measurements of the release of platelet granules in response to aggregating agents and arachidonic acid, and measurements of platelet factors released into the circulating blood, are probably more useful than simple aggregation tests. ${ }^{1011}$

In round two of the platelet saga, in the 1970 s, some of the many agents that had been found to modify platelet behaviour in vitro were tested in clinical trials to see whether they had an effect on thrombotic conditions. Aspirin, a potent inhibitor of the platelet release reaction and of the second phase of adenosine diphosphate induced aggregation, was the obvious drug to try, and early studies suggested that it might be beneficial for the secondary prevention of myocardial infarction. ${ }^{1213}$ The results of the largest trial, however (aspirin myocardial infarction study; AMIS), showed no benefit, ${ }^{14}$ although there are doubts whether the dose of aspirin was appropriate. ${ }^{15}$

Twenty years ago dipyridamole (Persantin) was shown to inhibit various aspects of platelet function, ${ }^{16}$ and it is now widely used as an antithrombotic agent. The evidence of its efficacy is not convincing, although it is thought to inhibit the formation of thrombus in patients with artificial heart valves or dialysis shunts, ${ }^{17} 18$ and in combination with aspirin it may prevent a second myocardial infarction ${ }^{19}$ or the occlusion of a coronary vein graft. ${ }^{20}$ Further trials are needed to confirm these effects.

The $\mathrm{ED}_{50}$ method of assessing platelet aggregation does not seem to be affected by the recent use of aspirin, so clearly it is not measuring anything to do with platelet synthesis of thromboxane; thus it is not a complete test of platelet function and it should not be regarded as superior to simple aggregation measurements.

Our main problem in investigating the link between platelets and vascular disease is that we do not know which platelet function test, if any, is relevant to human thrombosis. Once a convincing clinical trial has shown that an agent that modifies platelet behaviour also inhibits thrombosis in man, we shall be able to look back to see which platelet test might have predicted the effect. Until we have such a trial there is no reason to suppose that any one test is superior to another or, indeed, that platelet function tests are of any importance at all in vascular disease.

Professor of Cardiology,

J R HAMPTON

University Hospital

Queen's Medical Centre

Nottingham NG7 2UH

1 Duguid JB. Thrombosis as a factor in the pathogenesis of coronary atherosclerosis. Fournal of Pathology and Bacteriology 1946:58:207-15.

2 Born GVR. Aggregation of blood platelets by adenosine diphosphate and its reversal. Nature 1962; 194:927-9.

3 Heptinstall S, Mitchell JRA. Platelets and thrombosis. In: Biggs R, Rizza CR, eds. Human blood coagulation haemostasis and thrombosis. 3rd ed. Oxford: Blackwell Scientific Publications, 1984: $380-414$

4 Emmons PR, Mitchell JRA. Post-operative changes in platelet-clumping activity. Lancet 1965; $1-4$

5 Wright HP. Changes in the adhesiveness of blood platelets following parturition and surgical operations. Fournal of Pathology and Bacteriology 1942;54:461-8.

6 Hellem AJ. The adhesiveness of human blood platelets in vitro. Scand f Clin Lab Invest 1960;12: suppl 51
7 Hampton JR, Mitchell JRA. Platelet electrophoresis: the present position. Thrombosis et Diathesis Haemorrhagica 1974;31:205-44.

8 Hampton JR, Gorlin R. Platelet studies in patients with coronary artery disease and in their relatives. Br Heart $\mathcal{F}$ 1972;34:465-71

9 Turpie AGG, McNicol GP, Douglas AS. Platelet electrophoresis: effect of defibrination by ancrod (Arvin). Cardiovasc Res 1972;6:104-11.

10 Heptinstall S, Mulley GP, Taylor PM, Mitchell JRA. Platelet release reaction in myocardial infarction. Br Med J 1980;280:80-1.

1 Pumphrey CW, Dawes J. Plasma beta-thromboglobulin as a measure of platelet activity. Effects of risk factors and findings in ischemic heart disease and after acute myocardial infarction. Am $\mathcal{f}$ Cardiol 1982;50:1258-61.

12 Elwood PC, Cochrane AL, Burr ML, et al. A randomised controlled trial of acetylsalicylic acid in the secondary prevention of mortality from myocardial infarction. BrMed 7 1974; i:436-40. PC Sweetn PM. Aspirin and secondary mortality after myocardial infarction. Lance 1979;ii:1313-6.

AMIS. A randomized controlled trial of aspirin in persons recovered from myocardial infarction. IAMA 1980;243:661-9.

15 Hanley SP, Bevan J, Cockbill SR, Heptinstall S. Differential inhibition by low dose aspirin of human venous prostacyclin synthesis and platelet thromboxane synthesis. Lancet 1981;i:969-71 6 Emmons PR, Harrison MJG, Honour AJ, Mitchell JRA. Effect of dipyridamole on human platelet behaviour. Lancet 1965;ii:603-5.

7 Sullivan JM, Harken DE, Gorlin MD. Pharmacologic control of thromboembolic complications of cardiac-valve replacement. $N$ Engl F Med 1968;279:576-80.

18 Jacques $\mathrm{C}$, Drueke $\mathrm{T}$, Nedellec $\mathrm{O}$, et al. Les anomalies de l'hémostase chez les sujets en hémodialyse chronique, notamment compliquée de thromboses itératives des fistules artérioveineuses. Effets du dipyridamole [English Abstract]. Pathol Biol (Paris) 1976;24(suppl):27-32. 19 PARIS. Persantine and aspirin in coronary heart disease. Circulation 1980;62:449-61

20 Chesebro JH, Clements IP, Fuster V, et al. A platelet-inhibitor-drug trial in coronary-artery bypass operations. Benefit of perioperative dipyridamole and aspirin therapy on early postoperative vein-graft patency. N Engl f Med 1982;307:73-8.

\section{Cochlear implants}

Help for those with loss of hearing has developed from the cupped hand and ear trumpet to the reconstruction of the ossicular chain by modern microsurgical techniques and the amplification of sound with tiny hearing aids. These techniques cannot, however, help everyone with impaired hearing, for patients with total neurosensory deafness have no appreciation of any sort of acoustic stimuli however well amplified. Furthermore, the size of this group appears to be getting bigger-possibly because of increased survival after meningitis, head injuries, and serious illness requiring treatment with ototoxic drugs.

Electrical charges play a part in neuronal transmission, and since 1957 workers have been trying to stimulate the auditory nerve directly with an electric current to obtain a sensation of sound. ${ }^{12}$ Despite encouraging responses the problems of placing an electrode on to the intrapetrous or intracranial portion of the auditory nerve were not resolved easily, so attention turned to the use of an electrode threaded into the cochlea. ${ }^{3}$ Such a system has been developed by House in Los Angeles and prostheses of this type are now on sale. The system is simple and has proved resistant to permeation by tissue fluids. It consists of an electrode implanted inside the cochlea that receives impulses through a coil transmitting across the skin behind the ear. The stimuli are derived from a box which transforms speech into electrical impulses. In appearance the prosthesis is similar to the old style hearing aid.

Experiments have shown that altering the rate of impulses gives a sensation of change in pitch, albeit within narrow limits for the range is adequate at very low frequencies only. Full perception of vowel sounds and consonants is not possible, and the higher frequencies remain elusive. These limitations led to attempts at inserting multiple electrodes into the cochlea in the hope that differential stimulation of the nerve endings, sometimes with different frequency bands for each electrode, might improve perception and result in contrasts in timbre which would improve the recognition of speech. ${ }^{4 \cdot 6}$ Unfortunately, these techniques have not been as successful as expected, and the complex implanted electronics have been difficult to encapsulate adequately. 